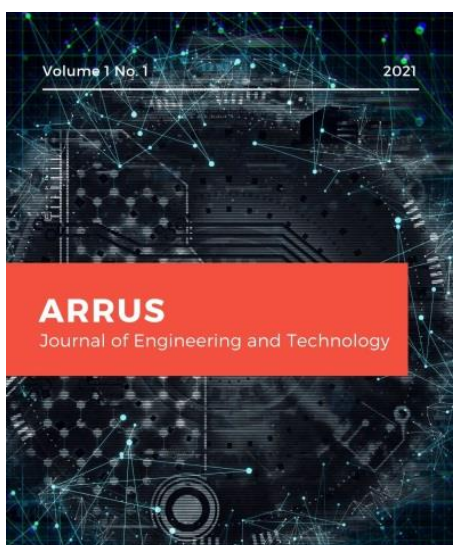

*Corresponding author: Rahmat Triandi, Informatich Engineering, Faculty Engineering, Malikussaleh University, Lhokseumawe City, Indonesian

E-mail:

rahmat.170170067@mhs.unimal.ac.id
RESEARCH ARTICLE

\section{Futsal Field Selection Application Using Mobile-GIS and GPS With Dijkstra's Algorithm Method (Lhokseumawe City Case Study)}

\author{
Rahmat Triandi*, Asrianda, \& Lidya Rosnita \\ Department of Informatics Engineering, Faculty of Engineering, Malikussaleh \\ University, Indonesia
}

\begin{abstract}
Futsal field rental is a business engaged in the field of community service in the field of futsal sports. Currently in lhokseumawe city there are 10 futsal fields located in various places, ranging from around campus, office areas, to densely populated settlements. This resulted in many of the people who do not know the location of the futsal field and also the nearest route that can be passed. So it takes an application that can provide information on the futsal field in lhokseumawe city along with the nearest route that can be passed. Determining the nearest route passed to the location of the futsal field can only be done on nodes that have been defined by the system. Dijkstra's algorithm was chosen because it operates thoroughly against existing nodes, and generates the shortest trajectory of all nodes so that it will produce the nearest route optimally. To test the accuracy of the nearest route the results of dijkstra algorithm implementation are used another software that is quantum GIS. This is done to see if the resulting path is correct. From the test results obtained the path obtained is the same as quantum GIS calculations with a similarity value of $100 \%$. Black box testing is used to test the functionality of the menus in the system, and the test results in terms of the functionality of the menus on the system run as desired and run well. The system is good to use.
\end{abstract}

Keywords: Selection, Dijkstra's Algorithm, GPS, Mobile-GIS 
save fuel, save time and energy. With the reference in determining which path to be passed can make it easier for users in choosing the fastest path to get to the location of the intended futsal field and not get lost in the middle of the road.

Therefore, the author intends to create an information technology such as futsal field selection application that is equipped with the shortest route search using Dijkstra Algorithm. An application that can do the selection of futsal fields that you want to use based on the nearest location or the desired futsal field with the navigation owned by this application will direct users to the chosen futsal field.

The purpose of the futsal field selection application system that utilizes GPS and GIS using Dijkstra Algorithm can make it easier for customers to get convenience in finding the location of the futsal field that is equipped with Global Positioning System (GPS) technology that serves as a global navigation that can direct customers using the fastest route to the intended futsal field location.

\section{Literature Review}

Dijkstra algorithm was invented by Edger W. Dijstra which is one of the variants of the popular algorithm form in solving problems related to optimization problems and is simple. This algorithm solves the problem of finding the shortest path (a path that has a minimum length) and Ivartex a to vartex $\mathrm{z}$ in a weighted graph, the weight is a positive number so it cannot be traversed by a negative node, but also happens so, then the solution given is infinity (Geovani, 2016).

Dijkstra's algorithm was chosen because it operates thoroughly against the existing alternative functions, and generated the shortest trajectory of all nodes (Lubis, 2009). In addition, it is also explained in other studies that Dijkstra Algorithm executes its programs faster than the Bellman-Ford Algorithm assuming there is no negative value. Negative value means that every distance between intersections must have a value, and the unit of value is always positive(Irawan, 2011). In addition, Dijkstra's algorithm can solve some cases of the shortest path, among others: the search for the shortest path between two nodes (a pair shortest path), the search for the shortest path between all pairs of shortest path, the search for the shortest path from a particular node to all other nodes (single-source shortest path) and the search for the shortest path between two nodes that go through certain nodes (intermediate shortest path) (Ratnasari et al., 2013).

\subsection{Steps of Dijkstra Algorithm}

In his writings it is said that the basic idea of Dijkstra Algorithm itself is to find the closest cost value to the goal that functions on a weighted graph, so that it can help provide a choice of paths. In dijkstra's algorithm, nodes are used because dijkstra's algorithm uses a directions graph for determining the route of the shortest trajectory. The algorithm aims to find the shortest path based on the smallest weight from one point to another. Suppose the point depicts the building and the line describes the road, then dijkstra algorithm performs calculations of all possible smallest weights of each point. In figure 1 presented an example of a graph with its weight in determining the path using dijkstra algorithm.

First determine which point will be the starting node, then weight the distance on the first node to the nearest node one by one, Dijkstra Algorithm will perform search development from one point to another and to the next step by step. The logical sequence of Dijkstra's algorithm is as follows (Ardana \& Saputra, 2016):

1. Give a weight value (distance) for each point to another point, then set the value 0 on the initial node and the infinite value with respect to other nodes(unfilled).

2. Set all nodes untouched and set the starting node as the departure node.

3. From the departure node, consider the untouched neighboring node and calculate its distance from the departure point. 
4. When we finish considering each distance to the neighboring node, mark the touched node as the touched node. The touched node will never be checked back, the distance saved is the last distance and the most minimal weight.

5. The set of nodes has not been touched with the smallest distance (from the departure node) as the next departure node and continues by returning to step number 3 .

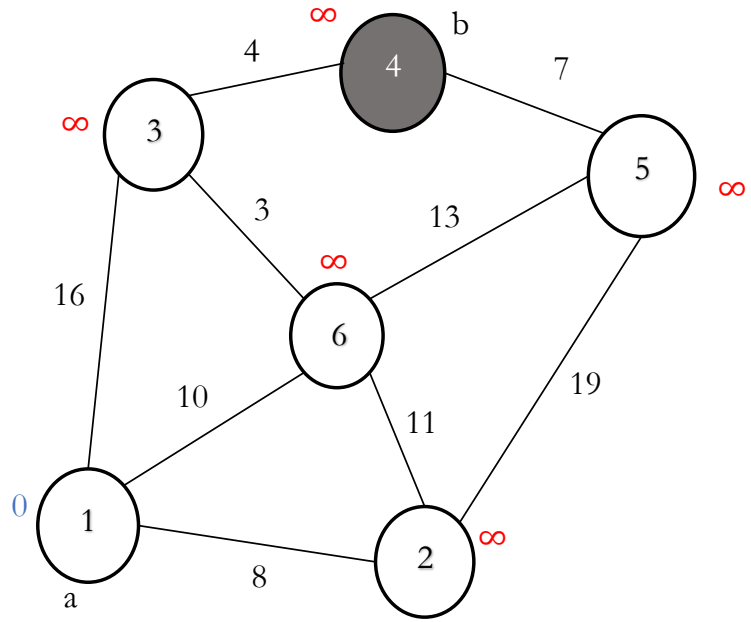

Figure 1: Examples find paths using Dijkstra's Algorithm

Dijkstra's algorithm can also be solved by using the Minimum Value Formula in each node passed by the following rules (Korte \& Vygen, 2000):

$$
\operatorname{dist}[x] \leftarrow \min \{\operatorname{dist}[x], \operatorname{dist}[u]+c[u, x]\}
$$

\section{Indices:}

$\operatorname{dist}[x]$ is the value in the vertex of the goal

$\operatorname{dist}[u] \quad$ is the value in the initial vertex

$c[u, x]$ is the value of the side that connects between vertex

Here's a summary meeting presented in the table below.

Table 1: Completion Process Example Case Figure 1

\begin{tabular}{c|c|c|c|c|c|c|c}
\hline i & $\operatorname{dist}[1]$ & $\operatorname{dist}[2]$ & $\operatorname{dist}[3]$ & $\operatorname{dist}[4]$ & $\operatorname{dist}[5]$ & $\operatorname{dist}[6]$ & $\operatorname{dist}[\mathrm{x}]$ \\
\hline 0 & 0 & $\infty$ & $\infty$ & $\infty$ & $\infty$ & $\infty$ & $\{1\}$ \\
\hline 1 & - & $\begin{array}{c}\operatorname{Min}\{\infty, 0+ \\
8\}=8\end{array}$ & $\begin{array}{c}\operatorname{Min}\{\infty, 0+ \\
16\}=16\end{array}$ & $\infty$ & $\infty$ & $\begin{array}{c}\operatorname{Min}\{\infty, 0+ \\
10\}=10\end{array}$ & $\{1,2\}$ \\
\hline 2 & - & - & 16 & $\infty$ & $\operatorname{Min}\{\infty, 8+$ & $\operatorname{Min}\{10,8+$ & $\{1,6\}$ \\
\hline 3 & - & - & $\operatorname{Min}\{16,10+$ & $19\}=27$ & $11\}=10$ & $\{1,6,3\}$ \\
\hline 4 & - & - & $3\}=13$ & $\infty$ & $\begin{array}{c}\operatorname{Min}\{27,10+ \\
13\}=23\end{array}$ & $\{1,6,3,4\}$ \\
\hline
\end{tabular}

Completion Results:

1. Starting from node 1 , at $\mathrm{i}=0$ node 1 is the starting point of departure and is taken as the first permanent point worth 0 . 
2. Starting from node $2, i=1$ has a value smaller than $i=4$ so that node 2 is passed first before node 6 .

3. Starting from node $6, i=2$ has the same value as $i=1$ so node 2 is ignored and replaced with node 6 on $i=1$.

4. Starting from node $3, i=3$ has a value smaller than $i=4$ so that node 3 is first passed before node 4 .

So, the shortest route from node 1 to node 4 is $1 \rightarrow 6 \rightarrow 3 \rightarrow 4$ with the total distance being 17 .

\section{Research Method and Materials}

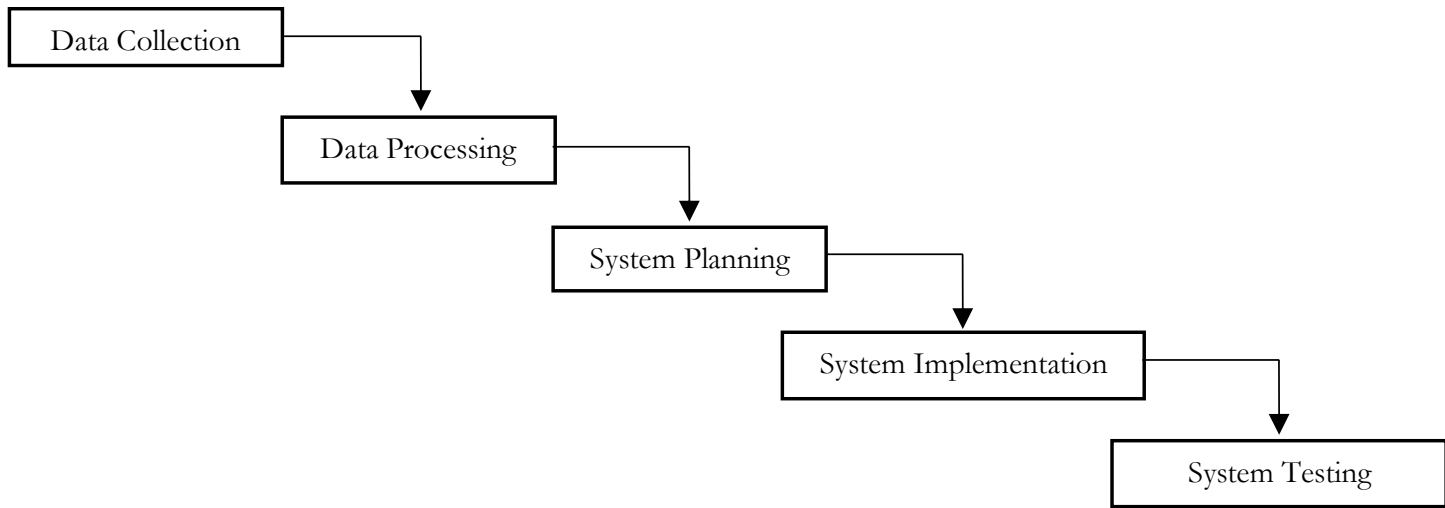

Figure 2: Research Methods

In this study has been compiled various research methods that will be done systematically. The research methods carried out are:

\section{1) Data Collection}

a) Primary Data

Primary data is the main data used in this study, this study uses futsal field location data in Lhokseumawe with the help of Google Maps to get coordinate data for each futsal field location.

b) Secondary Data

Secondary data is data that becomes additional data but has an influence in research, in this study the secondary data needed is destination data, and maps.

2) Data Processing

a) Create a destination or destination point and determine the departure location based on the location where the user is located.

b) Create graphs from the user's destination and location data. The location of the user based on sample data is the informatics building as the point of departure, and the crossroads is represented as a point, while the relationship and length of the road between intersections are represented in labeled graphs that have weights.

c) Determine the shortest route using dijkstra algorithm.

3) System Planning

System design uses Context Diagrams, DFD and ERD. Which is where this design will help the application development process that uses a programming language.

4) System Implementasyion

System implementation is the process of developing applications using a programming language. In this case will be used programming languages such as PHP, and Java. 
5) System Testing

System testing is done by performing stages of testing and debugging programs to ascertain whether it can run properly in accordance with the previously made design.

\section{Results and Discussion}

In this study will be taken a sample of departure points, namely from the Malikussaleh University Informatics Engineering Building to the futsal field in Lhokseumawe City as a destination point using Dijkstra Algorithm to get the shortest route. Regarding the process of representing the locations of destinations and streets in Lhokseumawe City in the form of labeled and weighted graphs.

Here are the steps representing the locations and streets of Lhokseumawe City in the form of labeled and weighted graphs.

1. Take and save photos of lhokseumawe city map through google earth.

2. Determine the point of the Malikussaleh University Informatics Engineering Building (point of origin) and the futsal field in Lhokseumawe City (destination point).

3. Draw a straight line to connect the point of origin with the destination point.

4. Determine the cutting points of the road to be traversed from the point of origin to the destination point.

5. Collect data in the form of:

a) Coordinates and addresses/names of futsal field locations as destination addresses, and coordinates of each road cutting point given the symbol Tn, where $\mathrm{n}$ is the integer and weight of each point (Tn) connected.

b) Information about the futsal field in the form of pictures, names, addresses, and mobile phone numbers of futsal field owners.

6. Create a labeled and weighted graph, which connects the existing vertices.

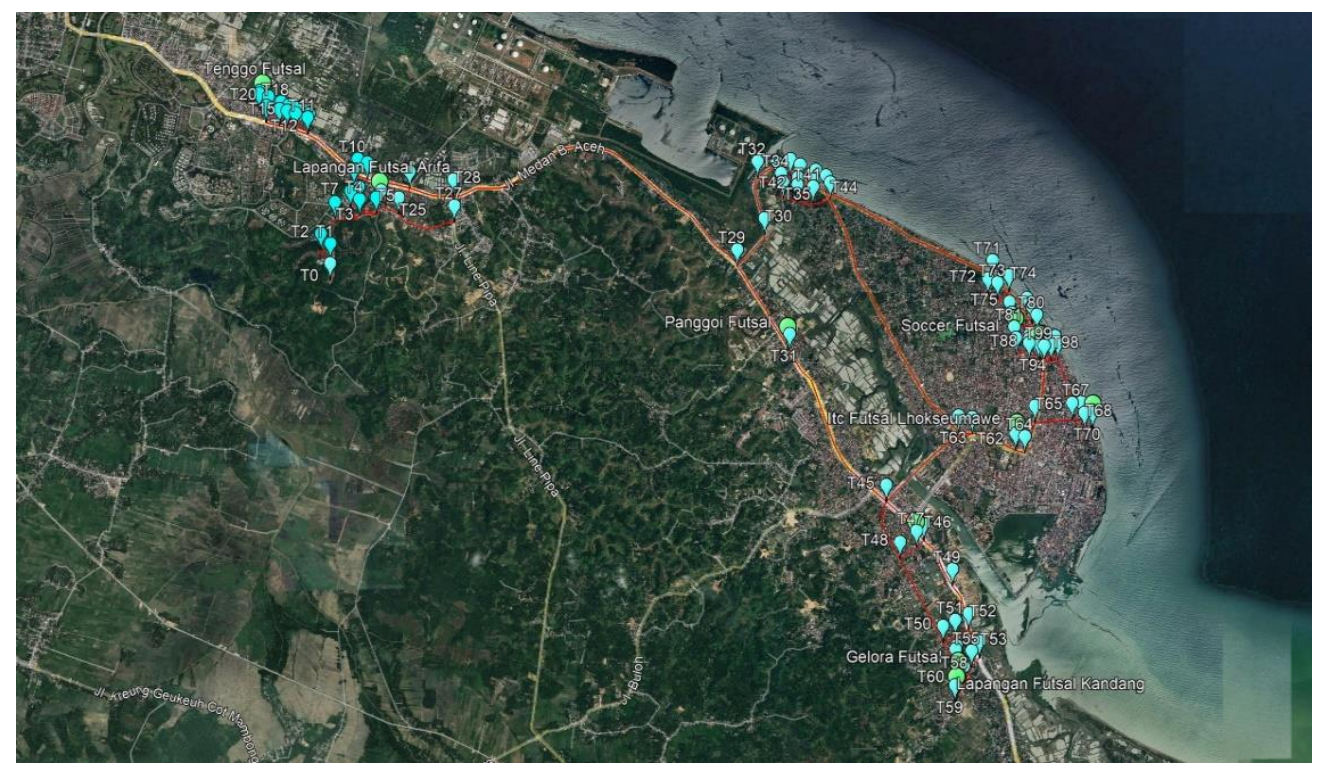

Figure 3: Road Section Cutting Node

Table 2: Location of Futsal Field in Lhokseumawe City

\begin{tabular}{c|c|c|c} 
No & Field Name & Field Address & Google Maps Coordinates \\
\hline \multirow{2}{*}{1} & Garuda Futsal & Jl. Darussalam, Gg. Pandan / Delia, South & 5.191260529356932, \\
& Arena & Hagu, Banda Sakti, Lhokseumawe City, Aceh & 97.14606972642261 \\
\hline \multirow{2}{*}{2} & Lhokseumawe & Panggoi Futsal & Panggoi, Muara Dua, Kota Lhokseumawe, \\
& Aceh & $\begin{array}{c}5.192092507737742, \\
97.1168500205992\end{array}$ \\
\hline
\end{tabular}


ISSN : 2776-7914 (Print) / 2807-3045 (online)

\begin{tabular}{|c|c|c|c|}
\hline No & Field Name & Field Address & Google Maps Coordinates \\
\hline 3 & $\begin{array}{c}\text { ITC Futsal } \\
\text { Lhokseumawe }\end{array}$ & $\begin{array}{l}\text { Simpang Empat, Banda Sakti, Kota } \\
\text { Lhokseumawe, Aceh }\end{array}$ & $\begin{array}{l}5.181267566230963 \\
97.14352328409319\end{array}$ \\
\hline 4 & Soccer Futsal & $\begin{array}{c}\text { Hagu Teungoh, Banda Sakti, Kota } \\
\text { Lhokseumawe, Aceh }\end{array}$ & $\begin{array}{l}5.193025637833038, \\
97.14336061292855\end{array}$ \\
\hline 5 & Aloh Futsal & $\begin{array}{l}\text { Uteun Kot, Muara Dua, Kota Lhokseumawe, } \\
\text { Aceh } 24355\end{array}$ & $\begin{array}{l}5.170155714801331 \\
97.13175272457524\end{array}$ \\
\hline 6 & $\begin{array}{l}\text { Lapangan Futsal } \\
\text { Arifa }\end{array}$ & $\begin{array}{l}\text { Blang Pulo, Muara Satu, Kota Lhokseumawe, } \\
\text { Aceh } 24355\end{array}$ & $\begin{array}{l}5.208453279751917 \\
97.06929948409328\end{array}$ \\
\hline 7 & Tenggo Futsal & $\begin{array}{c}\text { Batuphat Timur, Muara Satu, Kota } \\
\text { Lhokseumawe, Aceh }\end{array}$ & $\begin{array}{l}5.219818136155919 \\
97.05555685341074\end{array}$ \\
\hline 8 & Gelora Futsal & $\begin{array}{l}\text { Cot Girek, Muara Dua, Kota Lhokseumawe, } \\
\text { Aceh } 24355\end{array}$ & $\begin{array}{l}5.154478305284174 \\
97.13665742642249\end{array}$ \\
\hline 9 & $\begin{array}{l}\text { Lapangan Futsal } \\
\text { Kandang }\end{array}$ & $\begin{array}{c}\text { Cut Mamplam, Muara Dua, Kota } \\
\text { Lhokseumawe, Aceh } 24355\end{array}$ & $\begin{array}{l}5.152769033271508, \\
97.13644225525773\end{array}$ \\
\hline 10 & $\begin{array}{l}\text { Lapangan Futsal } \\
\text { Lr.bandeg }\end{array}$ & $\begin{array}{l}\text { Jl. Iskandar Muda, Kp. Jawa Lama, Banda } \\
\text { Sakti, Kota Lhokseumawe, Aceh }\end{array}$ & $\begin{array}{l}5.183391540613161 \\
97.15237823991657\end{array}$ \\
\hline
\end{tabular}

\subsection{Calculation of Dijkstra Algorithm}

In the calculation of Dijkstra Algorithm in this study, the departure point is set in the Informatics Engineering Building and the destination point is set in Tenggo Futsal. Here is an explanation of the process of finding the shortest route from the Informatics Engineering Building to Tenggo Futsal.

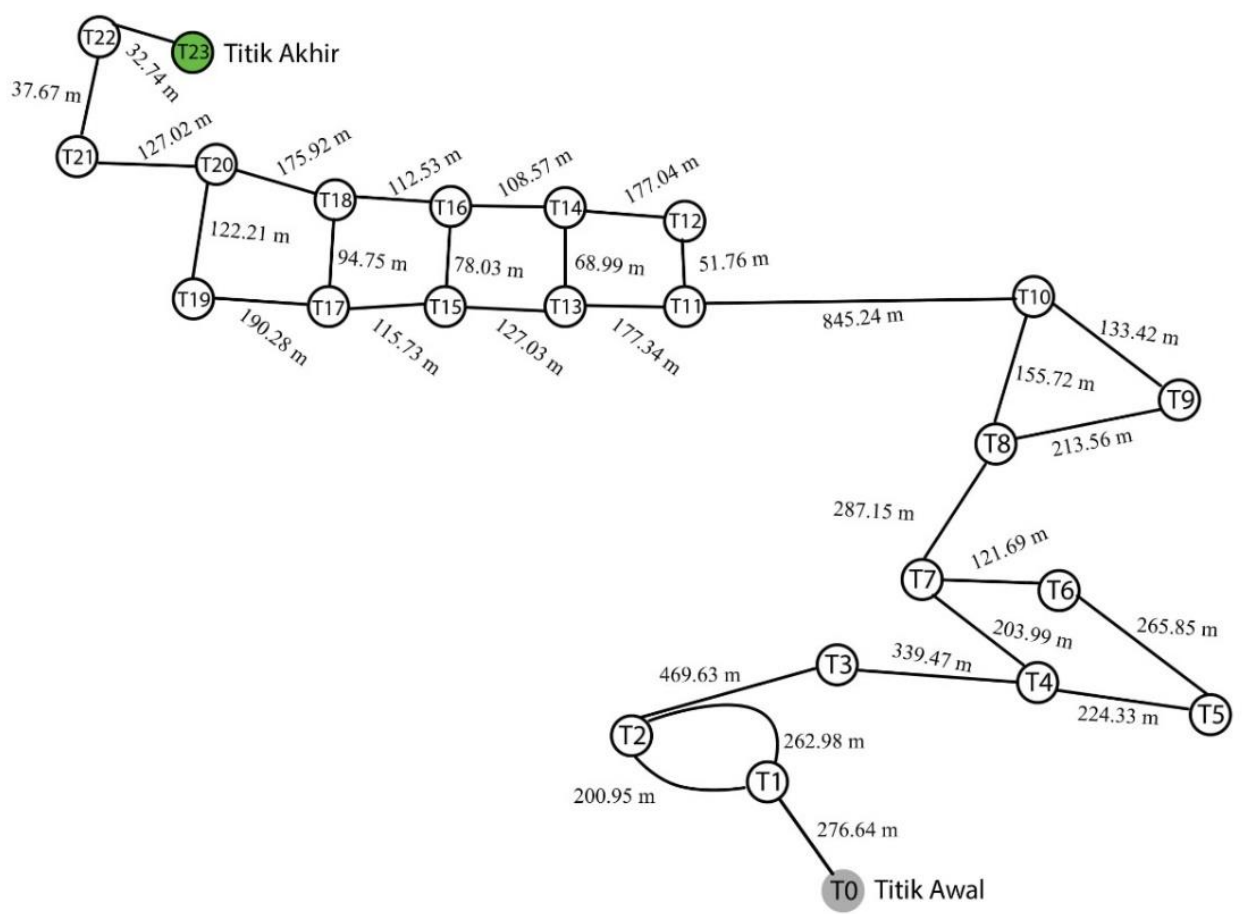

Figure 4: Labeled and Weighted Graphs From Informatics Engineering Building to Tenggo Futsal

Table 3: Distance of Each Point (Tn) Connected

\begin{tabular}{c|c|c|c}
\hline \multirow{2}{*}{ Point (Tn) Connected } & Distance & Point (Tn) Connected & Distance \\
\hline T0-T1 & 276.64 & T11-T13 & 177.34 \\
\hline T1-T2 & 200.95 & T12-T14 & 177.04 \\
\hline T1-T2 & 262.64 & T13-T14 & 68.99 \\
\hline T2-T3 & 469.63 & T13-T15 & 127.03 \\
\hline T3-T4 & 339.47 & T14-T16 & 108.57 \\
\hline
\end{tabular}


ISSN : 2776-7914 (Print) / 2807-3045 (online)

\begin{tabular}{c|c|c|c}
\hline T4-T5 & 224.33 & T15-T16 & 78.03 \\
\hline T4-T7 & 203.99 & T15-T17 & 115.73 \\
\hline T5-T6 & 265.85 & T16-T18 & 112.53 \\
\hline T6-T7 & 121.69 & T17-T18 & 94.75 \\
\hline T7-T8 & 287.15 & T17-T19 & 190.28 \\
\hline T8-T9 & 213.56 & T18-T20 & 175.92 \\
\hline T8-T10 & 155.72 & T19-T20 & 122.21 \\
\hline T9-T10 & 133.42 & T20-T21 & 127.02 \\
\hline T10-T11 & 845.24 & T21-T22 & 37.67 \\
\hline T11-T12 & 51.76 & T22-T23 & 32.74 \\
\hline
\end{tabular}

The shortest route from the Informatics Engineering building marked with the symbol T0 to Tenggo Futsal marked with the symbol T23 can be traveled with a total distance of 3602.02 meters with the following details:

$\mathrm{T} 0 \rightarrow \mathrm{T} 1 \rightarrow \mathrm{T} 2 \rightarrow \mathrm{T} 3 \rightarrow \mathrm{T} 4 \rightarrow \mathrm{T} 7 \rightarrow \mathrm{T} 8 \rightarrow \mathrm{T} 10 \rightarrow \mathrm{T} 11 \rightarrow \mathrm{T} 12 \rightarrow \mathrm{T} 14 \rightarrow \mathrm{T} 16 \rightarrow \mathrm{T} 18 \rightarrow \mathrm{T} 20 \rightarrow \mathrm{T} 21$

$\rightarrow \mathrm{T} 22 \rightarrow \mathrm{T} 23$

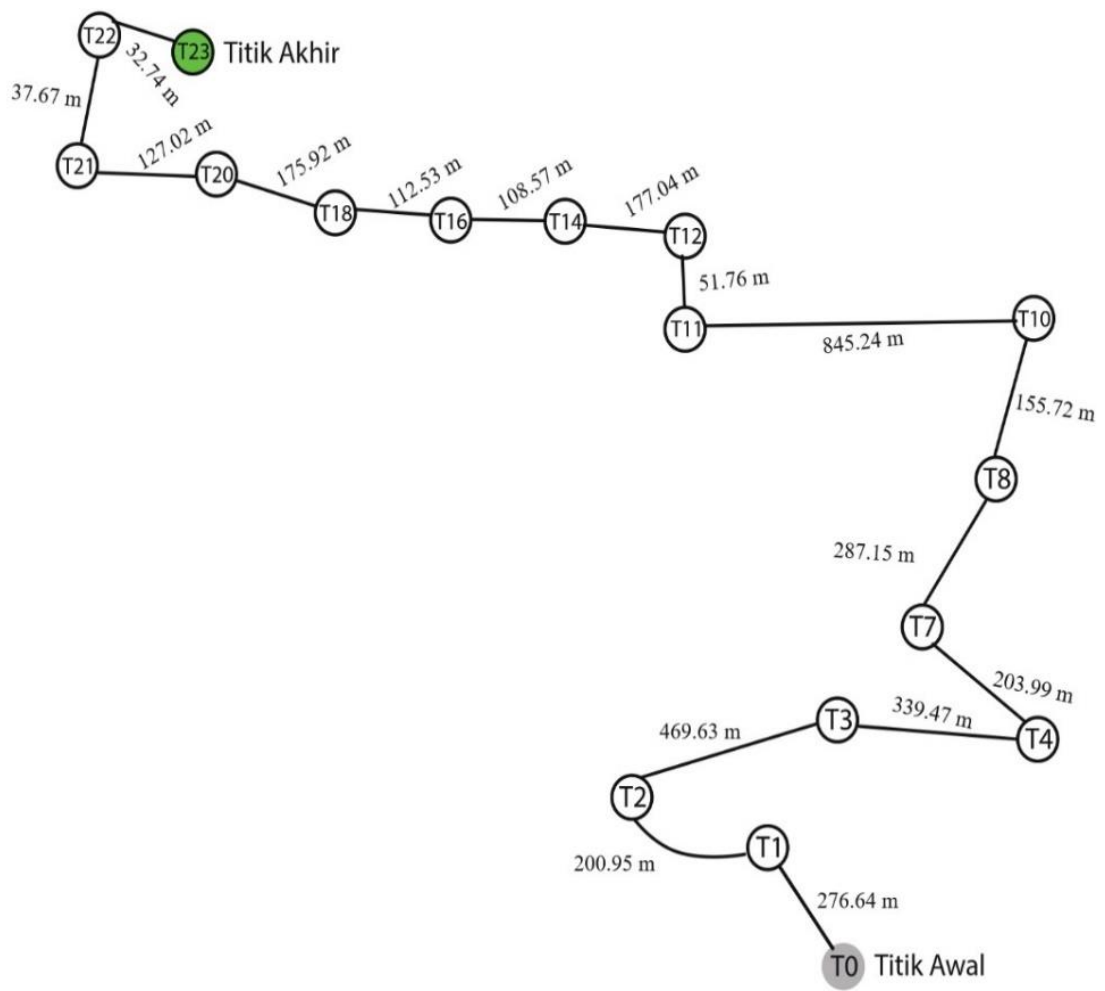

Figure 5: Shortest Route in Graph Form

\subsection{System Implementation Results}

The author implemented the above design by using an Android-based platform in the creation of futsal Field Selection Application Using Mobile-GIS and GPS With Dijkstra Algorithm Method. Here's a look at the system that's been implemented.

a) Splash Screen

This is the page that will first appear when the application is running. 


\section{b) Current location of application users and Futsal Field Marker}

It is a page that will automatically focus the Google Maps camera to where the application user is located. On this page will also display Marker which is the location of the futsal field in the city of Lhokseumawe.

\section{c) Search of the Nearest Futsal Field}

On this page, users can search the nearest futsal field from where the user is located, or choose the desired futsal field to get the nearest route.

\section{d) View Nearby Routes and Travel Navigation}

On this page will be displayed the nearest route after the user chooses the location of eight futsal who want to go. In the application users can also ask google maps for help to display travel navigation to direct users to the desired location.

\section{e) List of Futsal Field and Field Description}

On this page users can see a list of futsal fields in Lhokseumawe City. Users can also get a brief description of the futsal field consisting of the name of the field, futsal field address, and also a mobile number that can be contacted by users through the Whatsapp application or contact him directly.

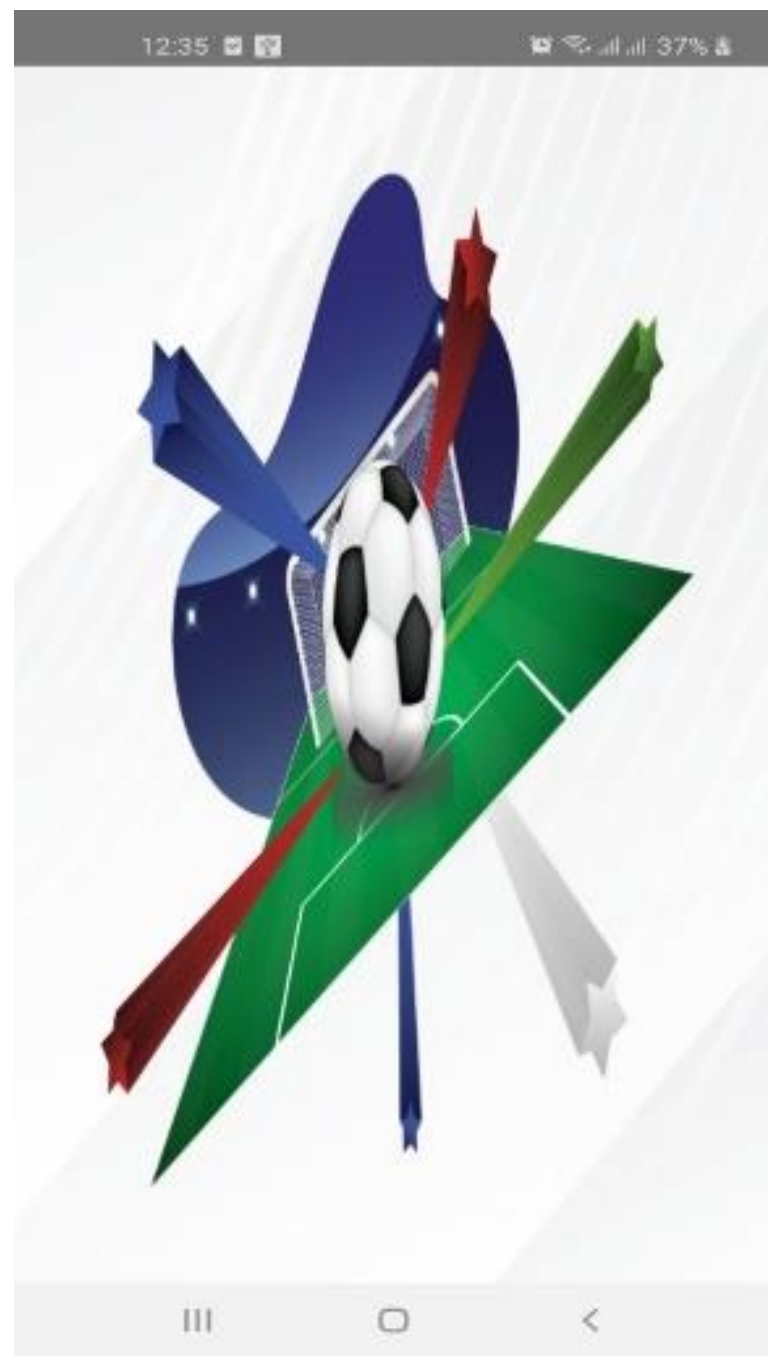

Figure 6: Splash Screen 
ISSN : 2776-7914 (Print) / 2807-3045 (online)
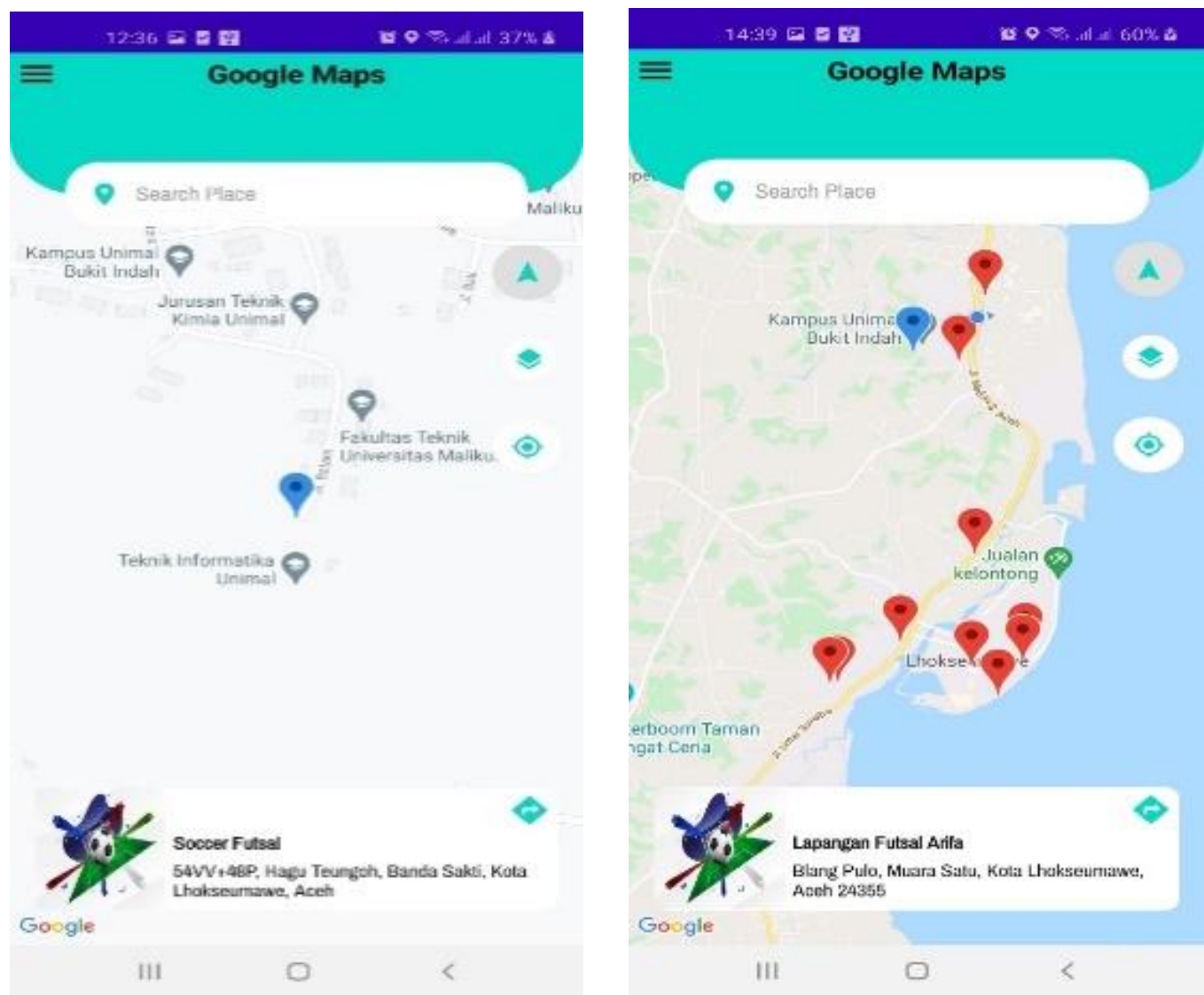

Figure 7: Application User Location and Futsal Field Marker

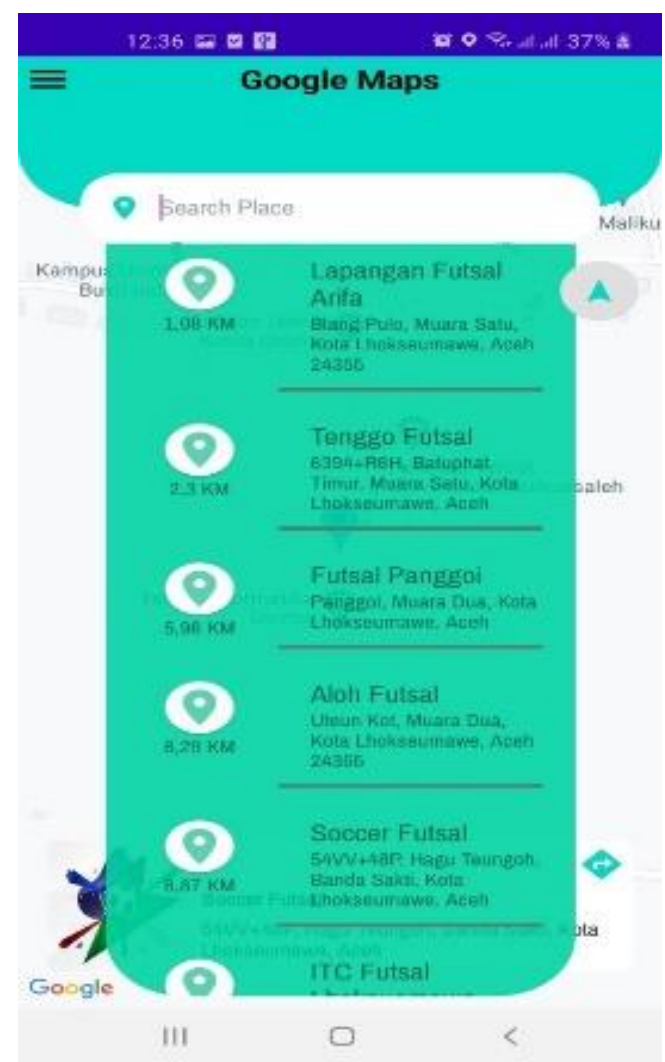

Figure 8: Nearest Futsal Field Search View 

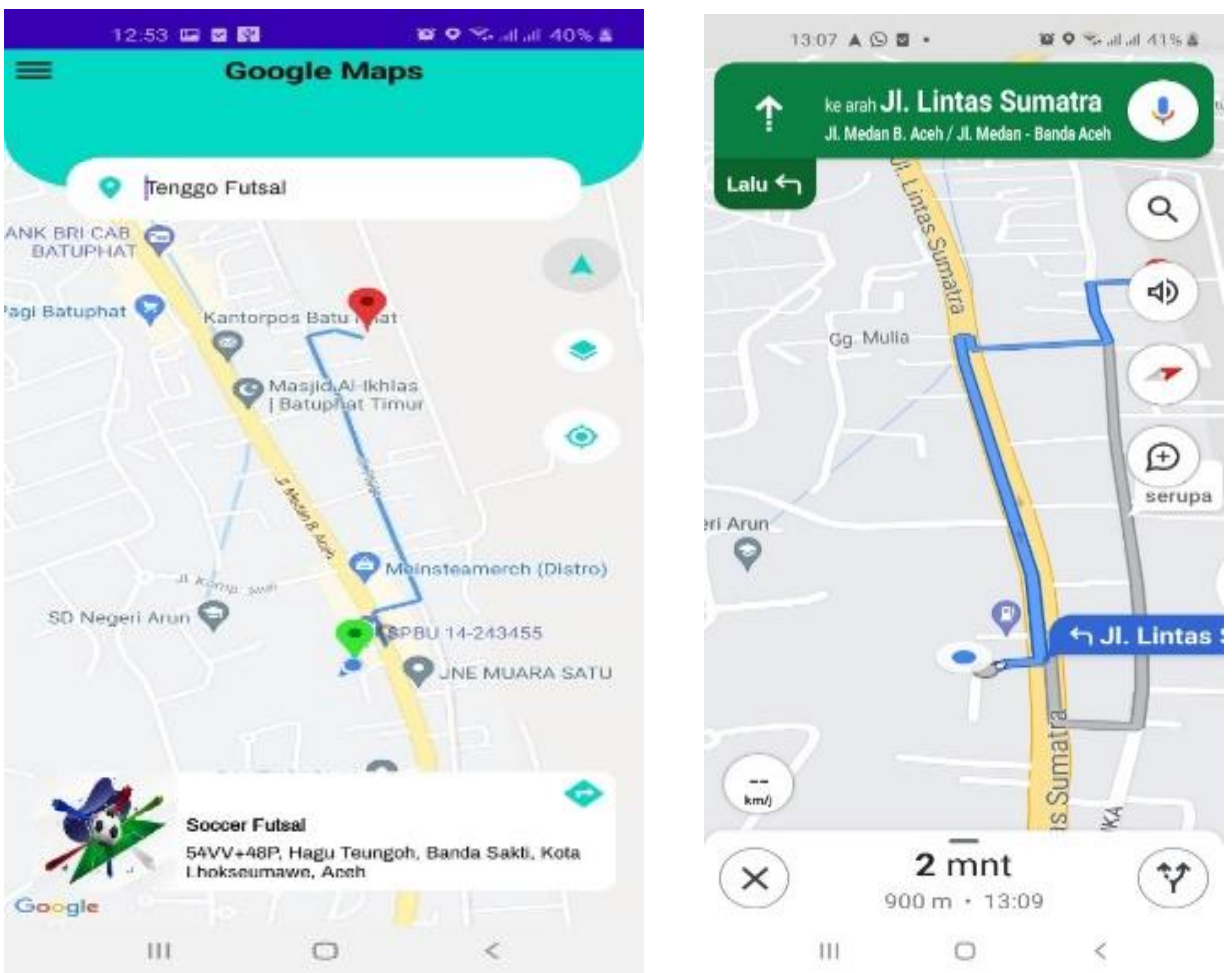

Figure 9: Closest Route View and Travel Navigation
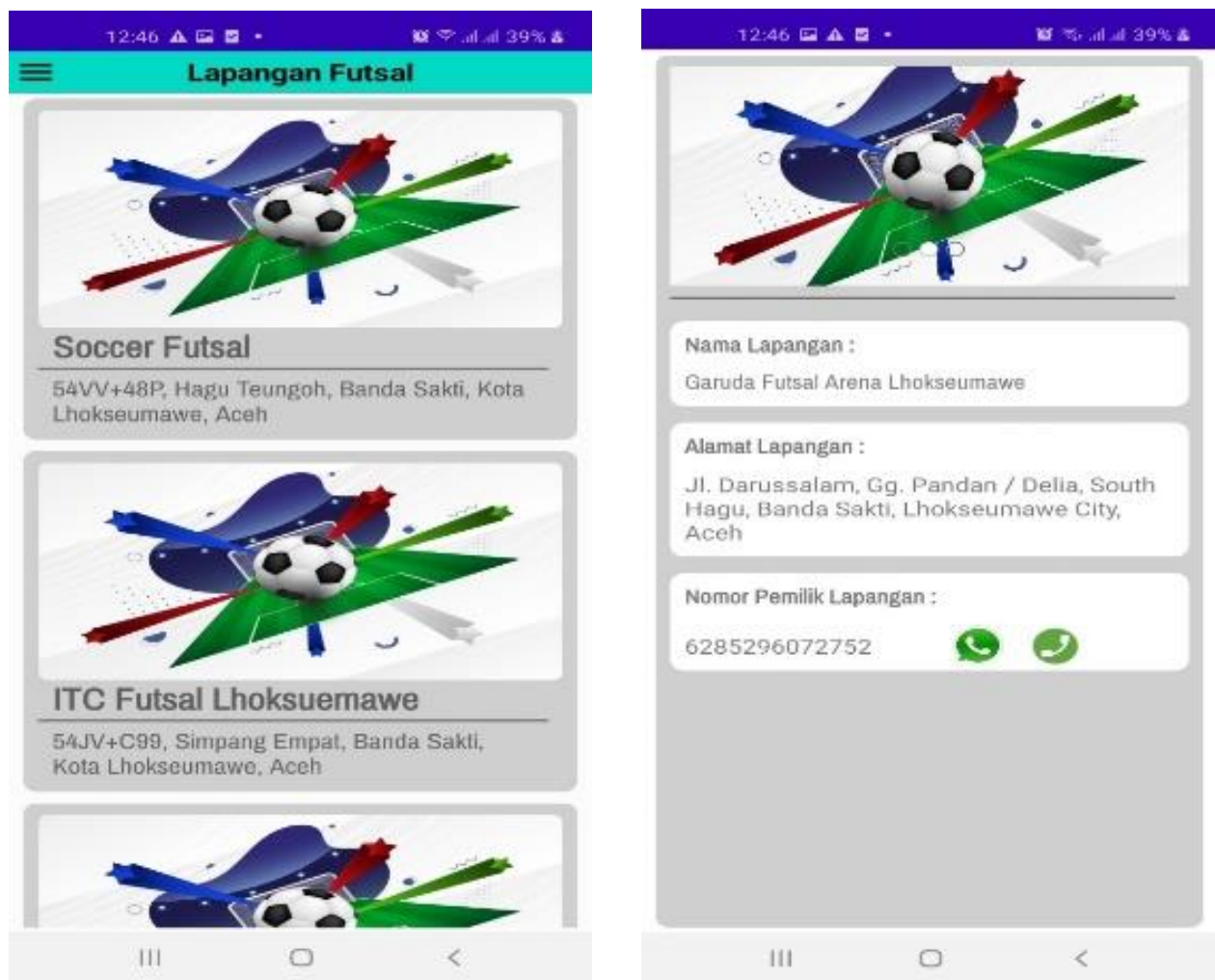

Figure 10: List of Futsal Fields and Futsal Field Description 


\section{Conclusion}

Based on the stages that have been compiled before, the conclusions that can be taken are as follows:

1. The system is based on Android that can help users in finding futsal fields in Lhokseumawe City and provide information on futsal field photos, futsal field addresses and phone numbers of futsal field owners.

2. The application of Dijkstra Algorithm on the built system can be used to determine the location of the closest distance so as to assist the application user in determining the closest route from where the user is to the location of the intended futsal field.

3. Not yet able to consider the type of vehicle that can pass the shortest route that has been determined and also the congestion of a road so that the route given can be the shortest route but not the best route.

4. Road data includes highways, as well as narrow alleys and also village roads that can still be passed.

5. The system built is only able to determine the shortest route from the previously defined route data so that there are still some lines that have not been defined.

\section{References}

Ardana, D., \& Saputra, R. (2016). Penerapan Algoritma Dijkstra pada Aplikasi Pencarian Rute Bus Trans Semarang. Skripsi Jurusan Ilmu Komputer, Fakultas Sains Dan Matematika, Universitas Diponegoro, Snik, 299-306.

Geovani, H. A. R. (2016). Implementasi Algoritma Dijkstra Untuk Mengetabui Lokasi Tempat Ibadab Umat Muslim Di Kota Malang Pada Aplikasi Mobile Phone (Studi Kasus Tempat Ibadab Di Wilayah Kecamatan Lowokwaru) [Universitas Islam Negeri Maulana Malik Ibrahim].

Irawan, M. P. (2011). Perbandingan Algoritma Dijkstra dan Algoritma Bellmand-Ford Pada Jaringan Grid. In Skripsi (Vol. 4, Issue 3). Universitas Andalas.

Korte, B., \& Vygen, J. (2000). Shortest Paths. COMPSCI 220 Algorithms and Data Structures, 139-152. https://doi.org/10.1007/978-3-662-21708-5_7

Lubis, H. S. (2009). Perbandingan Algoritma Greedy Dan Dijkstra Untuk Menentukan Lintasan Terpendek. In Skripsi. Universitas Sumatera Utara.

Ratnasari, A., Ardiani, F., \& A, F. N. (2013). Penentuan Jarak Terpendek dan Jarak Terpendek Alternatif Menggunakan Algoritma Dijkstra Serta Estimasi Waktu Tempuh. Semantik 2013, 3(1), $29-34$. 